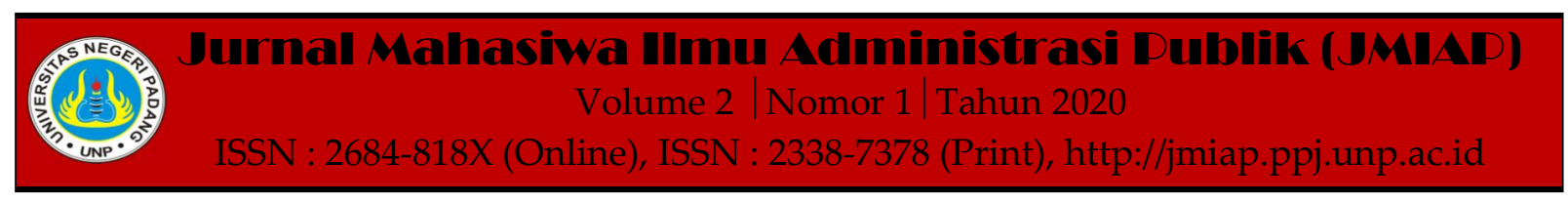

\title{
ANALISIS PELAKSANAAN PROGRAM KOTA LAYAK ANAK (KLA) DALAM MEMENUHI HAK SIPIL DAN KEBEBASAN ANAK DI KOTA PEKANBARU
}

\author{
Abdiana Ilosa ${ }^{1(\mathrm{a})}$, Rusdi $^{2(\mathrm{~b})}$ \\ ${ }^{1}$ Jurusan Administrasi Negara, Universitas Islam Negeri Sultan Syarif Kasim Riau \\ ${ }^{2}$ Jurusan Administrasi Negara, Universitas Islam Negeri Sultan Syarif Kasim Riau \\ a)abdiana@uin-suska.ac.id, ${ }^{b}$ rusdihalis72@gmail.com
}

\begin{abstract}
This research aims to study how the analysis of the implementation of child-friendly city programs in fulfilling civil rights and child freedom in the city of Pekanbaru. The background of the writer to carry out this research is Pekanbaru City has received KLA awards which increase every year, wherein 2015-2017 received pratama (best bottom level) ranks, in 2018 rose again to become an intermediate, and received the best Children's Forum award, the last year 2019 received 3 Awards namely rising ranks to nindya (the best level up), getting an award for child-friendly schools, dam Childfriendly Puskesmas. This type of research is qualitative research with descriptive methods and informant selection techniques. To answer the research objectives, researchers used indicators from the Minister of Women Empowerment and Child Protection Regulation No. 12 of 2011 concerning Child-Friendly District / City Indicators. The results of this study regarding the implementation of the KLA Program in fulfilling civil rights and freedom of children in the city of Pekanbaru so far has been running better than before, although it has not been able to contribute high scores to reach the Child-Friendly City category. Obstacles in the implementation process are from the factor of funds that are still minimal and still come from PAD, there is no cooperation with the private sector, then in terms of Human Resources because of frequent changes of officials so they must be re-socialized to new officials about the KLA. Lastly, regulations that have not been too binding on all regional apparatus organizations $(O P D)$ for total harmony in realizing the KLA program.
\end{abstract}

Keywords : Public Policy, Implementation, Child Friendly Cities (KLA), Civil Rights, Children's Freedom

Corresponding author.Email.abdiana@uin-suska.ac.id,rusdihalis72@gmail.com

How to cite this article. Ilosa, A \& Rusdi. (2020). Analisis Pelaksanaan Program Kota Layak Anak (KLA) dalam Memenuhi Hak Sipil dan Kebebasan Anak di Kota Pekanbaru. Jurnal Mahasiwa Ilmu Administrasi Publik (JMIAP) Jurusan Ilmu Administrasi Negara Fakultas Ilmu Sosial Universitas Negeri Padang, Volume 2 (1), Hal. 87-101.

http://jmiap.ppj.unp.ac.id

ISSN : 2684-818X (Online), ISSN : 2338-7378 (Print)

Copyright $\bigcirc 2020$. Published by Pusat Kajian-Pemberdayaan dan Pelayanan Masyarakat (PK-P2M) FIS UNP Padang 


\section{PENDAHULUAN}

Anak merupakan kelompok penduduk yang punya potensi untuk dikembangkan agar bisa berkontribusi dalam pencepatan pembangunan. Oleh karena itu sangat penting untuk membina mentalitas serta moralitas anak. Agama Islam mendefenisikan "anak-anak adalah manusia yang tidk ditentuka usia pastinya tetapi dilihat dari kapan dia mulai menstruasi buat peempuan dan kapn dia mimpi basah untuk laki-laki, dan jika hal tersebut suah terjadi maka anak tadi sudah dikatakan dewasa menurut agama. Sedangkan UU RI No.23 Tahun 2002 tentang Perlindungan Anak pasal 1 angka 1 "sesorang yang berusia dibawah 18 tahun dan juga termasuk yang masih dalam kandungan" Walaupun banyak defenisi tentang anak tetapi pada perinsipnya semua memberikanimplikasi yang sama, yaitu membeikan perlindungan kepada anak.

Untuk memberikan perlindungan anak ini pemerintah Indonesia menindaklanjuti dengan membuat Program Kota Layak Anak yang tertuang dalam Peraturan Menteri Negara Pemberdayaan Perempuan dan Perlindungan Anak No 11 Tahun 2011 tentang Kebjakan Pengembangan Kabupaten/ Kota Layak Anak, selanjutnya dikelurkan Peraturan Menteri Negara Pemberdayaan Perempuan dan Perlindungan Anak No 12 Tahun 2011 tentang Indikator Kabupaten/ Kota Layak Anak, diteruskan dengan Peraturan Menteri Negara Pemberdayaan Perempuan dan Perlindungan Anak No 13 Tahun 2011 tentang Panduan Pengembangan Kabupaten/ Kota Layak Anak.

Tujuan KLA secara umum untuk memenuhi hak dan melindungi anak, secara khusus untuk membangun inisiatif pemerintahan kabupaten/kota yang mengarah pada upaya transformasi Konvensi Hak Anak (Convention on the Rights of the Child) dari kerangka hukum ke dalam definisi, strategi dan intervensi pembangunan, dalam bentuk: kebijakan, program dan kegiatan pembangunan yang ditujukan untuk pemenuhan hak dan perlindungan anak (PHPA), pada suatu wilayah kabupaten/kota.

Keberadaan KLA akan membeikan kontribusi bagi kesejahteraan anak, khususnya untuk masyarakat yang tinggal dan menetap di suatu wilayah. Kontribusi yang diberikan misalnya, anak mampu memanfaatkan waktu luang untuk kegiatan budaya, serta yang terpenting untuk mendapatkan hak-haknya sepeti perlindungan dari tindakan kriminal, kekerasan, pelecehan seksual yang dapat membahyakan anak. Progran KLA meurupakan program yang bertujuan untuk menigkatkan kepedulian dan upaya kongkrit aparat pemeintah baik di Kabupaten/Kota maupun di Desa/Kelurahan, Keluaga, Masyarakat, dan Dunia usaha dalam upaya mewujudkan pembangunan kawasan yang menjamin pemenuhan hak-hak anak. kemudian untuk menyatukan potensi sumber daya manusia, sumber daya alam, sumber dana, sarana, prasarana dan teknologi yang ada pada pemeintah, partisipasi masyarakat serta unit usaha yang ada di Desa/Kelurahan dalam memenuhi hak-hak anak.

Dalam pelaksanaannya KLA mengacu pada 5 klaster hak anak yang harus dipenuhi, yang terdiri dari 6 indikator kelembagaan dan 25 indikator subtansi. 5 kalster nya adalah 1). Hak Sipil dan Kebebasa; 2).Lingkungan Keluarga dan Pengasuhan Alternatif; 3).Kesehatan dan Kesejahteraan Dasar; 4). Pendidikan, pemanfaatan waktu luang dan kegiatan budaya; dan 5).Perlindungan khusus.

Pada tahun 2015 Kota Pekanbaru menjdi anggota KLA di tingkat Pratama sampai 2017, pada tahun 2018 Kota Pekanbaru mendapatkan 2 penghargaan yaitu naik ke tingkat Madya dan mendaptkan pengharga forum anak terbaik di Propinsi Riau. Kemudian pada tahun 2019 kembali Kota Pekanbaru mendapatkan tiga penghargaan dan juga naik tingkat menjadi Nindya, lalu mendapat penghargaan Sekolah Ramah Anak dan Puskesmas Ramah Anak. 
Abdiana Ilosa, Rusdi I Analisis Pelaksanaan Program Kota Layak Anak (KLA) dalam Memenuhi Hak Sipil dan Kebebasan Anak di Kota Pekanbaru

Tabel 1. Jumlah Anak Kota Pekanbaru Menurut Kelompok Umur dan Jenis Kelamin

\begin{tabular}{cccc}
\hline \multirow{2}{*}{$\begin{array}{c}\text { Kelompok Umur } \\
\text { (Tahun) }\end{array}$} & \multicolumn{2}{c}{$\begin{array}{c}\text { Jenis Kelamin } \\
\text { Laki-Laki }\end{array}$} & Perempuan \\
\hline $0-4$ & 57.467 & 52.551 & 110.018 \\
$5-9$ & 50.281 & 46.149 & 96.430 \\
$10-14$ & 45.936 & 42.577 & 88.513 \\
$15-18$ & 51.290 & 52.497 & 103.787 \\
\hline \multicolumn{3}{c}{ Jumlah Total } & 398.748 \\
\hline Sumber: BPS Kota Pekanbaru (Pekanbaru Dalam angka Tahun 2018)
\end{tabular}

Lebih dari 1/4 dari penduduk Kota Pekanbaru adalah anak- anak menurut UUD. Dengan angka yang sangat besar itu Progam KLA diharapkan bisa membantu dalam memenuhi Hak anak sesuai dengan tujuan dari KLA itu sendiri yaitu untuk membangun inisiati pemerintah Kota/ Kabupaten yang mengarahkan pada upaya transfomasi konversi hak-hak anak (Convention on the Right of Child) dai kengka hukum ke dalam defenisi, strategi, dan intervensi pembangunan dalam bentuk kebijakan, program, dankgiatan-kegiatan pembangunan yang ditunjukkan untuk pemenuhan hak-hak anak, pada suatu wilayah Kota/Kabupaten.

Dari kelima klaster Kota Layak Anak ini hanya dua klaster yang mendapatkan penghargaan pada tahun 2018 yaitu klaster pendidikan dan kesehatan anak. Oleh karna itu penulis tertarik meneliti tentang klaster yang belum mendapatkan penghargaan yaitu klaster hak sipil dan kebebasan anak.

Berdasarkan alasan diatas peniliti membuat judul penelitian "Analis Pelaksanaan Program Kota Layak Anak dalam Memenuhi Hak Sipil dan Kebebasan Anak di Kota Pekanbaru".

\section{TINJAUAN PUSTAKA}

\section{Kebijakan Publik}

Wiliiam N. Dunn (2003:132) menyebut istilah kebijakan publik dalam bukunya yang berjudul Analisis Kebijakan Publik, pengertiannya sebagai berikut:

"Kebijakan Publik (Public Policy) adalah pola ketergantungan yang kompleks dari pilihan-pilihan kolektif yang saling bergantung, termasuk keputusan-keputusan untuk tidak bertindak, yang dibuat oleh badan atau kantor pemerintah".

Kebijakan publik sesuai apa yang dikemukakan oleh Wiliam N. Dunn mengisyaratkan adanya pilihan-pilihan kolektif yang saling bergantung satu dengan yang lainnya, dimana didalamnya keputusan-keputusan untuk melakukan tindakan. Kebijakan publik yang dimaksud dibuat oleh badan atau kantor pemerintah. Suatu kebijakan apabila telah dibuat, maka harus di implementasikan untuk dilaksanakan oleh unit-unit administrasi yang memobilisasikan sumber daya finansial dan manusia, serta di evaluasikan agar dapat dijadikan sebagai mekanisme pengawasan terhadap kebijakan tersebut sesuai dengan tujuan kebijakan itu sendiri. Sedangkan definisi kebijakan publik menurut Easton ini dapat diklasifikasikan sebagai suatu proses menejemen, yang merupakan fase dari serangkaian kerja pejabat publik. Dalam hal ini hanya pemerintah yang mempunyai andil untuk melakukan tindakan kepada masyarakat untuk menyelesaikan masalah publik, sehingga definisi ini juga dapat diklasifikasikan dalam bentuk intervensi pemerintah. (Tangkilisan,2003: 2).

Kebijakan publik dapat juga diartikan sebagai pengalokasian nilai-nilai kekuasaan untuk seluruh masyarakat yang keberadaannya mengikat. Dalam hal ini hanya pemerintah yang dapat melakukan suatu tindakan kepada masyarakat dan tindakan tersebut merupakan bentuk dari sesuatu yang dipilih oleh pemerintah yang 
merupakan bentuk dari pengalokasian nilainilai kepada masyarakat.

Dalam kemajuan sistem pemerintahan yang semakin modern saat ini kita tidak lepas dengan kebijakan publik yang banyak ditemui diberbagai bidang kepemerintahan seperti bidang kesejahteraan, bidang sosial, kesehatan, keamanan, pertanian, perekonomian dan lain sebagainya yang bertujuan untuk mengatasi masalahmasalah yang terjadi guna mencapai tujuan bersama dari berbagai definisi diatas yang dimaksud dengan kebijakan publik dalam penelitian ini adalah sekumpulan keputusan ataupun tindakan dan strategi yang digunakan pemerintah untuk memecahkan suatu masalah publik.

\section{Implementasi Kebijakan}

Secara etimologis pengertian implementasi menurut Kamus Webster yang dikutip oleh Solichin Abdul Wahab adalah:

"Konsep implementasi berasal dari bahasa inggris yaitu to implement. Dalamkamus besar webster, to implement (mengimplementasikan) berati to provide the means for carrying out (menyediakan sarana untuk melaksanakan sesuatu); dan to give practical effect to (untuk menimbulkan dampak/akibat terhadap sesuatu)"(Webster dalam Wahab, 2004:64)"

Implementasi berasal dari Bahasa Inggris yaitu to implement yang berarti mengimplementasikan. Implementasi merupakan penyediaan sarana untuk melaksanakan sesuatu yang menimbulkan dampak atau akibat terhadap sesuatu. Sesuatu tersebut dilakukan untuk menimbulkan dampak atau akibat itu dapat berupa undang-undang, peraturan pemerintah, keputusan peradilan dan kebijakan yang dibuat oleh lembagalembaga pemerintah dalam kehidupan kenegaraan.

Implementasi kebijakan pada prinsipnya merupakan cara agar sebuah kebijakan dapat mencapai tujuannya. Lester dan Stewart yang dikutip oleh Winarno, menjelaskan bahwa implementasi kebijakan adalah: "Implementasi kebijakan dipandang dalam pengertian luas merupakan alat administrasi hukum dimana berbagai aktor, organisasi, prosedur dan teknik yang bekerja bersama-sama untuk menjalankan kebijakan guna meraih dampak atau tujuan yang diinginkan" (Lester dan Stewart dalam Winarno, 2002:101-102).

Kesimpulannya adalah implementasi merupakan tindakan-tindakan yang dilakukan oleh pemerintah untuk mencapai tujuan yang telah di tetapkan dalam suatu keputusan kebijakan. Akan tetapi pemerintah dalam membuat kebijakan juga harus mengkaji terlebih dahulu apakah kebijakan tersebut dapat memberikan dampak yang buruk atau tidak bagi masyarakat. Hal tersebut bertujuan agar suatu kebijakan tidak bertentangan dengan masyarakat apalagi sampai merugikan masyarakat.

\section{Program Kota Layak Anak (KLA)}

Konsep KLA adalah Kabupaten/Kota yang mempunyai sistem pembangunan berbasis hak anak melalui pengintegrasian komitmen dan sumber daya pemerintah, masyarakat dan dunia usaha, yang terencana secara menyeluruh dan berkelanjutan dalam kebijakan, program dan kegiatan untuk menjamin terpenuhinya hak dan perlindungan anak.

Tujuan KLA secara Umum: Untuk memenuhi hak dan melindungi anak dan secara Khusus: Untuk membangun inisiatif pemerintahan kabupaten/kota yang mengarah pada upaya transformasi Konvensi Hak Anak (Convention on the Rights of the Child) dari kerangka hukum ke dalam definisi, strategi dan intervensi pembangunan, dalam bentuk: kebijakan, program dan kegiatan pembangunan yang ditujukan untuk pemenuhan hak dan perlindungan anak (PHPA), pada suatu wilayah kabupaten/kota. 
Prinsip dalam Pengembangan KLA (1) Non diskriminasi; (2) Kepentingan yang terbaik untuk anak; (3)Hak untuk hidup, kelangsungan hidup dan perkembangan; (4) Penghargaan terhadap pendapat anak; (5) Tata Pemerintahan Yang baik; (6)Apa Strategi Pengembangan "KLA".

KLA menerapkan strategi pemenuhan hak anak (PUHA), yang berarti melakukan pengintegrasian hak-hak anak ke dalam: (1) Setiap proses penyusunan: kebijakan, program dan kegiatan; (2) Setiap tahapan pembangunan: perencanaan dan penganggaran, pelaksanaan, pemantauan dan evaluasi. (3) Setiap tingkatan wilayah: nasional, provinsi, kabupaten/kota, kecamatan, hingga desa/kelurahan. Tingkat Penghargaan KLA diberi dengan 5 kategori yaitu:1. Kabupaten/kota Layak Anak; 2. Utama; 3. Nindya; 4. Madya;5. Pratama.

\section{Indikator Hak Sipil dan Kebebasan Anak}

Hak Sipil adalah hak kebebasan fundamental yang diperoleh sebagai hakikat dari keberadaan seorang manusia. Arti kata sipil adalah kelas yang melindungi hak-hak kebebasan individu dari pelanggaran yang tidak beralasan oleh pemerintah dan organisasi swasta, dan memastikan kemampuan seseorang untuk berpartisipasi dalam kehidupan sipil dan politik negara tanpa diskriminasi atau penindasan.

Hak-hak sipil yang ada di setiap negara dijamin secara konstitusional. Hak-hak sipil bervariasi di setiap negara karena perbedaan dalam demokrasi, namun mungkin untuk menunjukkan. beberapa hak-hak sipil yang sebagian besar tetap umum. Beberapa hak-hak sipil universal dikenal seseorang adalah kebebasan berbicara, berpikir dan berekspresi, agama serta pengadilan yang adil dan tidak memihak.

https://id.wikipedia.org/wiki/Hak-

hak_sipil_dan_politik.

Anak dari sisi kehidupan berbangsa dan bernegara adalah masa depan bangsa dan generasi penerus cita-cita bangsa, sehingga Negara berkewajiban memenuhi hak setiap anak atas kelangsungan hidup, tumbuh dan berkembang, berpartisipasi, perlindungan dari tindak kekerasan dan diskriminasi. Negara, pemerintah, masyarakat, keluarga dan orang tua berkewajiban dan bertanggung jawab terhadap penyelenggaraan perlindungan anak, karena anak dari sisi perkembangan fisik dan psikis manusia merupakan pribadi yang lemah, belum dewasa dan masih membutuhkan perlindungan.

Salah satu hak anak yang paling vital wajib dipenuhi adalah masalah sipil dan kebebasan yang meliputi: hak nama dan kewarganegaraan, hak mempertahankan identitas, hak kebebasan menyatakan pendapat, dan hak akses kepada informasi yang layak.

Lebih lanjut, sesuai dengan UndangUndang Nomor 10 tahun 1992 tentang Kependudukan, masalah hak sipil dan kebebasan anak, perlu pendekatan dari 4 (empat) matra, yakni anak sebagai individu/pribadi, anak sebagai penduduk, anak sebagai warga negara dan anak sebagai bagian dari komunitas masyarakat. Masyarakat sebagai lahan tumbuhnya benih-benih individu akan mendorong para anggotanya untuk berinteraksi secara benar serta berprilaku positif. Hal ini bisa terjadi dengan prasyarat jika para individu tersebut tumbuh dalam lingkungan masyarakat yang kondusif bagi perkembangan pribadinya.

Indikator KLA sesuai Peraturan Mentri PPPA No 12 Tahun 2011 Merupakan variabel yang digunakan untuk mengukur pelaksanaan pemenuhan hak anak di daerah dalam upaya mewujudkan KLA dan merupakan acuan bagi pemerintah, pemerintah provinsi, dan pemerintah kabupaten/kota dalam perencanaan, pelaksanaan, pemantauan dan evaluasi kebijakan, program dan kegiatan pemenuhan hak anak untuk mewujudkan KLA Terdiri dari 6 indikator kelembagaan dan 25 indikator subtansi yang dikelompokkan dalam 5 klaster hak anak. 


\section{METODE PENELITIAN}

Jenis penelitian ini adalah kualitatif dengan analis deskriftif. Penelitian kualitatif sebagai prosedur penelitian yang menghasilkan data deskriptif berupa katakata tertulis atau lisan dari orang-orang dan perilaku yang diamati dari fenomena yang terjadi ( Moleong : 2007 ). Kemudian Moleong (2007:11) mengemukakan bahwa penelitian deskriptif menekankan pada data berupa kata-kata, gambar, dan bukan angka-angka yang disebabkan oleh adanya penerapan metode kualitatif. Penelitian ini menggali fakta implementasi Program Kota Layak Anak Dalam Memenuhi Hak Sipil dan Kebebasan Anak di Kota Pekanbaru, dideskripsikan berdasarkan temuan yang diperoleh melalui wawancara, observasi, dan dokumentasi.

Penelitian ini dilakukan di Kota Pekanbaru dengan metode pengumpulan data observasi, wawancara dan dokumentasi. Subjek penelitian dalam penelitian ini memkai teknik purpusive sampling dengan teknik penentuan informan memakai key informan.. Adapun key informan pada penelitian dibawah ini:1).Kepala Seksi Pemenuhan Hak Anak bidang Sipil, Informasi, dan Partisipasi DPPPA Kota Pekanbaru; 2).Kepala Seksi Bidang Pencatatan Akte Kelahiran dan Akte Kematian Disdukcapil Kota Pekanbaru; 3).Masyarakat kota Pekanbaru yang Bersedia menjadi Informan dan mempunyai anak.

\section{HASIL DAN PEMBAHASAN Penguatan Kelembagaan}

Dalam rangka meningkatkan peran dan fungsi Forum Anak untuk menjadi Pelopor dan Pelapor dalam Pengarusutamaan Hak Anak pemerintah harus memperkuat kelembagaan nya. Karna disat kelembagaan kuat maka hasil dan tujuan dari kebijakan itu akan tercapai dan terlaksana dengai baik. Dalam pelaksanaan program Kota Layak Anak, kebijakan KLA yang telah ditetapkan dengan Peraturan Menteri Negara Pemberdayaan Perempuan Nomor 2 Tahun 2009, telah diperbarui dengan Peraturan
Menteri Negara Pemberdayaan Perempuan dan Perlindungan Anak Nomor 11 Tahun 2011 tentang Kebijakan Pengembangan Kabupaten/Kota Layak Anak, Peraturan Menteri Negara Pemberdayaan Perempuan dan Perlindungan Anak Nomor 12 Tahun 2011 tentang Indikator Kabupaten/Kota Layak Anak, dan Peraturan Menteri Negara Pemberdayaan Perempuan dan Perlindungan Anak Nomor 13 Tahun 2011 tentang Panduan Pengembangan Kabupaten/Kota Layak Anak. Selanjutnya harus ada peraturan daerah yang khusus tentang program Kota Layak Anak.

Dalam penelitian ini peneliti akan membahas tentang bagaimana pengutan kelembagaan tentang Program Kota Layak Anak di Kota Pekanbaru dengan sub indikator dibawah ini:

a) Adanya peraturan perundang-undangan dan kebijakan untuk pemenuhan hak anak

Pemerintah Kota Pekanbaru tahun 2019 meraih tiga penghargaan yakni sebagai KLA kriteria Nindya, Sekolah Ramah Anak dan Puskesmas Ramah Anak. Pada tahun sebelumnya 2018 Kota Pekanbaru naik peringkat dengan meraih pratama ke Madya atau peringkat ketiga Kota Layak Anak (KLA). Naik Status Kota Layak Anak di Kota Pekanbaru tidak terlepas dari Usaha segenap OPD (Organisasi Perangkat Daerah) dalam menjalankan indikatorinikator dari KLA yang tertuang dalam Peraturan Menteri Negara Pemberdayaan Perempuan dan Perlindungan Anak Nomor 12 Tahun 2011 tentang Indikator Kabupaten/Kota Layak Anak. Dalam hal ini Kepala Bagian Pemenuhan Hak Sipil (PHA) DPPPA menjelaskan bahwa Keberhailan Kota Pekanbaru ini merupakan bentuk apresiasi yang sangat luar biasa dan membanggakan, dalam wawancara beliau mengatakan

"hal ini tentunya merupakan bentuk apresiasi yang sangat luar biasa yang diberikan oleh Pemerintahan Pusat kepada kita dan juga kami dari pihak DPPPA yang menjadi salah satu OPD yang terlibat didalamnya merasa 
bangga dengan prestai ini” (wawancara : 25 September 2019).

Selanjutnya Pemerintahan Kota Pekanbaru menindak lanjuti Peraturan Mentri tentang pengembangan Kota Layak Anak dengan membuat Peraturan Daerah, dan RAPERDA nya sudah disahkan disahkan tinggal menunggu nomor register di Propinsi. Kalau sudah ada dan semua nya beres dan di sahkan tinggal tugas DPPPA mensosialisasikan kepada UPTD terkait, hal ini disampaikan oleh Ibu Nel Afni L, SKM,M.K.M selaku Kepala seksi Pemenuhan Hak Anak Di Bidang Hak Sipil, Informasi dan Partisispasi:

"Ranperda sudah disahkan tinggal menunggu nomor register di propinsi lalu noreg, Kalau sudah ada no dan semua nya selesai kemudian disahkan, tinggal tugas DPPPA mensosialisasikan kepada UPTD terkait”.

Tetapi sayangnya Pemkot Pekanbaru hanya mempunyai satu peraturan ini tentang penyelenggaraan Progran Kota Layak Anak di Kota/Kabupaten . belum ada Peraturan Wali Kota dan Turunan nya, tetapi hal ini udah termasuk kemajuan dari pada tahun sebelumnya. Hal ini diungkapkan oleh Ibu Nel Afni L, SKM,M.K.M selaku Kepala seksi Pemenuhan Hak Anak Di Bidang Hak Sipil, Informasi dan Partisispasi beliau mengatakan:

"kalau ini salah satu wujud keseriusan pemeintah dalam mewujutkan KLA. Dan ini juga langkah awal yang bagus, semoga peraturan turunan nya tentang KLA ini semakin banyak dan bertambah" (wawancara : 25 September 2019).

Dari hasil wawancara diatas disipulkan bahwa sudah ada inisiatif pemerintah untuk membuat peraturan khusus dalam mempercepat pelakasanaan KLA yaitu Peraturan Daerah tentang Penyelenggaran
Program Kota Layak Anak di Kota Pekanbaru

b) Peran Anak dalam membuat peraturan Karena tujuan dari program KLA ini adalah untuk memenuhi hak- hak anak maka seharusnya dalam membuat keputusan harus melibatkan anak-anak. Dalam penyusunan kebijakan RAPERDA ini anak-anak diundang untuk ikut serta pada rapat penyusunan kebijakan. Hal ini diungapkan oleh Nel Afni L, SKM,M.K.M selaku Kepala seksi Pemenuhan Hak Anak Di Bidang Hak Sipil, Informasi dan Partisispasi beliau mengatakan::

"Dalam penyusunan kebjakan ini kami sudah mengikuts ertakan anak-anak dengan cara mengundang mereka untuk ikut serta bersama anggota dewan dalam merumuskan kebijakan, anakanak yang di ikut sertakan adalah anak yang sudah sekolah tingakat SLTP dan SLTA karna anak SLTP dan SLTA sudah bisa diajak diskusi dan bisa menyampaikan aspirasinya sementara perwakitan dari anak SD, TK sampai kebawai diambil dari guru dan orangtua".

Jadi disimpulkan bahwa anak diikutsertakan dalam perumusan kebijakan karna tujuan kebijakn ini adalah untuk memenuhi hak anak jadi anak lah yang lebih paham apa yang mereka butuhkan

c) Sumber Daya

Untuk Sumber daya manusia sudah ada Gugus Tugas (GT) sampai sekarang berfungsi, didalam GT ini sudah diatur peran dan tugas masing. Hal ini disampaikan oleh Ibu Nel Afni L, SKM,M.K.M selaku Kepala seksi Pemenuhan Hak Anak Di Bidang Hak Sipil, Informasi dan Partisispasi beliau mengatakan:

"dalam hal perwujutan Kota Layak Anak, pemerintah sudah mempunyai Gugus Tugas, dan GT tersebut sampai skarang masih berjalan, dalam GT tersebut sudah diatur tugas dan tanggungjawab masing-masing, ketua 
GT adalah Sekretaris Daerah dengan Anggota seluruh perangkat daerah yang terkai" wawancara : 25 September 2019).

Selain itu sebagai wujud keseriuasan Pemkot juga terlihat disini dengan memberikan pelatihan rurin, yang terbaru ini Dinas Pemberdayaan Perempuan dan Perlindungan Anak Provinsi Riau menyelengarakan pertemuan "Bimbingan Teknis Gugus Tugas Kabupaten/Kota Layak Anak (KLA) Dengan Analisis Pengarusutamaan Hak Anak (PUHA) Angkatan Kedua Tahun 2019 pada tanggal 03-04 September 2019 bertempat di Hotel Jatra.

Dalam Kesempatan ini hadiri 40 orang Peserta dari Kabupaten-Kota yang telah menerima Anugerah KLA Tahun 2019 yaitu Kota Pekanbaru, Kota Dumai, Kabupaten Indragiri Hulu, Kabupaten Indragiri Hilir, Kabupaten Kampar dan Kabupaten Pelalawan, Adapun Narasumber dari Kementerian Pemberdayaan Perempuan dan Perlindungan Anak yaitu Taufieq Uwaidha, M.Si serta Rohika Kurniadi,SH, M.Si dengan paparan terkait Kebijakan dan Rencana Aksi Nasional terkait Perpres KLA, Tiem Mastina dari Bappeda Provinsi Riau dengan paparan terkait Peran Gugus Tugas KLA, T.Hidayati Effiza, MM dari Kepala Dinas PPPA Provinsi Riau dengan paparan terkait Progres Pelaksanaan KLA di Provinsi Riau serta Matridi Umar dari Narasumber Yayasan Intan Payung paparan Penyusunan Rencana Aksi Daerah KL. Kegiatan ini dilakukan dalam upaya Untuk Menguatkan komitmen dan peran Gugus Tugas KLA di Provinsi dan KabupatenKota melalui Pemetaan dan penguatan peran strategis Gugus Tugas KLA dalam mendorong pelaksanaan KLA serta Penyusunan Rencana Aksi Daerah KLA di Provinsi dan Kab/Kota. Hal ini disampaikan oleh Kepala Bagian Pemenuhan Hak Sipil (PHA) DPPPA.

"Pemerintah Propinsi Rutin membuat Bimbingan Teknis Gugus Tugas Kabupaten/Kota Layak Anak (KLA) dengan tema yang berbeda-beda, dan yang dilakukan beberapa waktu yang lalu dengan tema "Bimbingan Teknis Gugus Tugas Kabupaten/Kota Layak Anak (KLA) Dengan Analisis Pengarusutamaan Hak Anak (PUHA)",

Selain sumber daya manusia kita tidak bisa melupakan biaya, karena dalam pelaksanaan progran KLA ini pasti akan mengluarkan biaya yang tidak sedikit, sejauh ini biaya pelaksanaan peogram KLA ini murni dari PAD, dan APBD memang dianggarkan untuk pelaksanaan KLA. Hal ini diungkapkan oleh Ibu Nel Afni L, SKM,M.K.M selaku Kepala seksi Pemenuhan Hak Anak Di Bidang Hak Sipil, Informasi dan Partisispasi:

"dana untuk pelaksaan KLA ini semua dari PAD karna kita mengikuti UU otonmi daerah, dalam APBD juga sudah ada anggaran untuk pelaksanaan $K L A$, dan sejauh ini belum ada tambahan dana dari pihak swasta, sebenarnya bisa saja mengajukan proposal ke Pihak swasta yang ada di Kota Pekanbaru, dan bisa juga pemberian CSR. Walaupun kita sudah ada APSAI (Asosiasi Pengusaha Sahabat Anak Indonesia) tetapi belum berjalan karna baru dibentuk" (wawancara tangan 25 September 2019).

Selain dua hal diatas Sumber daya orgaisasi yaitu Kecamatan Layak Anak (KELANA) dan Desa Layak Anak (DELANA) juga lagi digalakkan oleh DPPPA, karna untuk mendapatkan tingkat Kota Layak Anak harus mengaktfkan samapai ke tingkat terendah. Hal ini disampaikan oleh Ibu Nel Afni L, SKM,M.K.M selaku Kepala seksi Pemenuhan Hak Anak Di Bidang Hak Sipil, Informasi dan Partisispasi:

"KELANA dan DELANA sudah mulai diaktifkan, tetapi belum maksimal, hal ini terbukti dengan pengukuhan 13 Forum Anak di 13 Kecamatan di Pekanbaru, pengukuan ini dilakanakan 
di kecamatan Tenayan Raya pada tanggal 1 Oktober yang Akan Datang, kami berharap ini langkah awal dalam memajuan KELANA dan DELANA sehingga bisa mecapai KLA".

Dari hasil wawancara diatas disimplkan bahwa untuk SDM sudah ada Gugus Tugas (GT) yang bernggotakan seluruh perangkat daerah yang terkait dan diketuai oleh SEKDA. Lanjut masalah anggaran / dana sejauh ini masih berasal dari APBD belum ada sumbangan dari pihak swasta.

d) Keterlibatan lembaga masyarakat dan Dunia Usaha dalam pemenuhan hak anak

Masalah lembaga masyarakat dalam hal pemenuhan hak anak dari hasil wawancara bersama Ibu Nel Afni L, SKM,M.K.M selaku Kepala seksi Pemenuhan Hak Anak Di Bidang Hak Sipil, Informasi dan Partisispasi beliau mengatakan:

"Karna kegiatan Program KLA ini DPPPA bisa bekerjasama dengan pihak negeri / swata, kalau ada kegiatan Di kota Pekanbaru ini LSM sekota pekanbaru, PKK, Wartawan organisasi manapun boleh masuk dan ikut bekerjasama. Karna ada dua tim pelopor dan pelapor, begitu juga dengan instansi pemerintah lain nya tidak harus ada MOU nya karna progran KLA ini adalah lintas sektor"

Berbeda lagi dengan instansi pemerintah lain nya mereka harus memiliki MOU dengan pihak swasta seperti Disdukcapil, bekerjasama dengan Rumah Sakit dalam penerbitan Akte Kelahiran dan Kartu Identitas Anak. Hal ini disebutkan oleh Ibu Sri wahyuni, S.STP selaku Kepala Seksi Bidang Pencatatan akte Kelahiran dan Kematian, beliau mengatakan:

"kami membuat MOU dengan 27 Rumah sakit di Kota Pekanbaru dalam membuat Akte kelahiran danKartu Identitas Anak, yang sebelum nya 23 Rumah Sakit, dengan pertimbangan disaat surat yang keterangan lahir dibawa pulang masyarakat suka banyak alasan untuk mengurusnya kembali, dengan inoasi ini kami berharap masyarakat merespon dengan baik dan mau membuat langsung Akte kelahiran Ataupun kartu Identitas Anak. Dari 26 Rumah sakit yang bekerjasama masih ada yang belum aktif dan ini menjadi PR kami kedepan" (wawancara 25 September 2019)

Kesimpulannya seluruh lembaga terkait bisa bekerjasama dengan DPPPA dalam hal pelaksanaan KLA karna mereka lintas sektor, begitu juga pihatk swasta karna ada nya pelopor dan pelapor. Tetapi instansi terkait percepatan pelaksanaan KLA seperti Disdukcapik Kota Pekanbaru harus ada MOU dengan pihak swasta.

\section{Identitas Anak}

a) Akte Kelahiran

Akte Kelahiran atau disebut juga Akte Lahi menurut Kamus Bahasa Indonesia adalah bukti berisi pernyataan yang sangat teramat penting dan guna menimpan dan mengatur bahan kketerangan tentang kelahiran seorang bayi dalam bentuk selembar kertas yang sudah divcetak. Akte Kelahiran adalah catatan resmi berdasarkan Undang-Undang, biasanya sebuah Akte lahir terdiri atas pencantuman beberapa maklumat sebagai berikut:

- Nama kelahiran

- Tanggal dan Waktu Kelahiran Anak

- Jenis Kelamin anak

- Tempat Kelahiran Anak

- Nama Kedua Orang tua dari Seorang Anak

- Pekerjaan Kedua Orang Tua dari Sorang Anak

- Berat dan Tinggi Badan Anak

- Nama seorang Juru Tunjuk Yang Mencatatkan Pendataran Kelahiran Anak

- Taggal Pencatatan Pendaftaran Kelahiran

- Tanda Tangan Pejabat berwenang

Jumlah anak yang udah memiliki akte kelhairan di Kota Pekanbaru pada tahun 
2018 telah mencapai $81,03 \%$ atau sekitar 322.986 jiwa. Hal ini menunjukkan Bahwa ada peningkatan karna di tahun 2019 yang belum berahir ini sudah $92 \%$, tetapi angka ini belum bisa menyumbang penghargaan KLA karna target penghargaan KLA itu adalah $100 \%$, yang menyumbang nilai banyak itu bidang pendidikan dan kesehatan, hal ini disampaikan oleh Sri wahyuni, S.STP selaku Kepala Seksi Bidang Pencatatan akte Kelahiran dan Kematian, beliau mengatakan:

"DisDukCapil tidak dapat penghargaan KLA, karena target KLA itu 100\% sementara kami hanya bisa 81,03\% ditahun 2018 dan 92\% ditahun 2019, yang menyumbang bnyak untuk KLA itu adalah bidang Pendidikan dan Kesehatan dan mereka mendapatkan penghargaan Sekolah Ramah Anak dan Puskesmas Ramah Anak."

Naiknya angka capaian ini tidak terlepas dari Kerjasama dengan pihak terkait. Untuk mempercepat pemenuhan target 100\% Disdukcapil membuat inovasi-inovasi seperti jemput bola dengan turun langsung ke UPTD dan bekerjasama dengan Dinas Pendidikan dengan meminta data anak di sekolah. Hal ini diungkapkan oleh ibu sri Wahyuni dalam wawancara tanggal 25 September :

"terahir ini kami turun ke kelurahan Bukit Raya ada 5 kelurahan, kami turun 4 hari, 2 hari kami turun langsung 2 hari lagi ke UPTD, kami menemukan masih banyak yang belum mempunyai akte kelahiran, salah satu alasan mereka tidak mengurus adalah karna waktu dan keterbatasan dana, karna mereka banyak yang awam berfikir setiap pengurusan surat menyurat akan membutuhakan biaya yang besar, sementara kenyataannya kalau diurus sediri Akte kelahiran itu gratis untuk anak usia dibawah 60 hari dan di denda 50 ribu setelah 60 hari, denda ini masih berlaku di Kota Pekanbaru dengan tujuan memberikan efek jera,. Jumlah denda ini jga diatur dalam Peraturan
Daerah. tetapi ketika program jemput bola ini kami gratiskan semua umur"

Kemudian disdukcapil juga bekerjasam dengan pihak sekolah untuk mendapatkan data anak-anak yang belum mempunyai Akte Lahir karna sekarang semua pengurusan tidak hanya untuk sekolah harus mempunyai akte lahir dan penyumbang terbanyak itu adalah pendatang yang bekerja di pekanbaru. Hal ini disampaikan oleh ibu Sriwahyuni:

"Banyak kasus keluarga pindah tanpa membawa surat-surat atau tidak memiliki identitas ini penyumbang terbesar anak tidak memiliki akte lahir. Harsnya yang udah ada dipindahkan, tetapi kalo tidak ada dibawa mereka bisa langung urus ke kasi pendaftaran penduduk bu eli, lalu dilakukan iris mata, misalnya pernah melalukan rekam di daerah lain maka dia harus pindahkan data, tetapi kalo tidak pernah merekam data dibuattkan NIK baru, hal ini sangat membantu masyarakat ttapi dengan catatn langsung datang endiri mengurusnya di Disdukcapil jangan pakai perantara, kalau pakai perantara biasa nya itu yang mengeluarkan uang banyak"

"Proses nya harus membuat pengantar $R T$ karna RT yang tahu sudah berapa lama dia tingal disitu lalu dibuatkan surat domisisli ke kelurahan lalu ke kecamatan baru ke disdukcapil untuk rekap data/scan mata, dll"

"Untuk yang pindah dari daerah lain yang jauh dan tidak membawa suratsurat kemudian tidak punya biaya untuk menejemputnya kembali juga bisa dibuatkan surat-surat nya dan tetap melapor ke bagian pencatatn urat pindah dan akan dibantu disana"

"untuk anak yang Cuma punya ibu bisa dibuatkan akte lahir dengan satu ibu"

"malah biaya penerbitan Akte Kelahiran Gratis ebelum 60 hari, lewat 60 hari yg 
urus langsung kenaa 50.000. Akte rusak 1 tahun, dan masih ttd kadis sekarang tidak dikenakan biaya, tetapi kalau 2 tahun kena denda 50.000”

"kemudian Disdukcapil juga membuat MOU dengan Rumah sakit yang ada di Kota Pekanbaru, sejauh ini masih tingat Rumah Sakit tetapi meningkat dari 23 sekarang sudah 27 walau masih ada yang belum aktif, dan ini menjadi PR kami kedepan nya"

Jadi Akte lahir ini sangat berguna dalam setiap pengurusan di negara ini, untuk anak ekolah dll. Karna itu Disdukcapil membuat inovasi sitem jemput bola dan kerjasama dengan pihak wasta / Rumah Sakit.

b) Kartu Identitas Anak (KIA)

Pemerintah melalui Kementerian Dalam Negeri mendorong pembuatan Kartu Identitas Anak. Hal tersebut sebagai ganti dari Kartu Tanda Penduduk (KTP) yang baru bisa dimiliki seseorang di usia 17 tahun. Aturan tersebut tertuang dalam Permendagri Nomor 2 Tahun 2016 tentang Kartu Identitas Anak. Saat ini, Kartu Identitas Anak terdiri dari dua jenis, yakni untuk anak usia 0-5 tahun dan 5-17 tahun.

Berdaarkan hasil wawancara dengan ibu Sri wahyuni malah KIA ini Kota Pekanbaru agak tertinggl dibanding kota yang lain.

"Kita memang tertinggal dengan kota lain masalah penerbitan KIA, tengah tahun ini saja kami masih mengumpulkan data dengan cara bekerjasama dengan dinas pendidikan kota karna SLTA tidak menjadi perioritas, kemudian Dinas menyurati sekolah untuk mendata siswanya dengan membawa syarat yaitu: KTP orangtua, Kartu Keluarga, Akte lahir (photo copi) umur 5 tahun keatas membawa pas photo. Dikumpulkan oleh pihk sekolah yang kemudian kami ambil ke sekolah. Kemudian juga MOU dengan Rumah Sakit untuk meminta data ank yang baru lahit. Sekarang kami sudah mulai menerbitkan KIA dan berharap kerjasama semua pihak terutama orang tua yang mempunya anak yang berumur dibawah 17 tahun"

"Program KIA ini kami fokuskan untuk anak SLTP kebawah karna pertimbangan anak SLTA sebentar lagi akan mendapatkan KTP, dan akan mubazir jika dibuatkan. Sementra dana nya tidak sedikit"

Kesimpulan mengenai KIA adalah Kota Pekanbaru baru mulai mecetak KIA bulan kemaren dan mereka juga membuat inovasi dengan jemput bola, kerjasam dengan instasi pemerintah lain dan juga membuat MOU dengan Rumah sakit sejalan dengan pembuatan Akte kelahiran.

\section{Fasilitas Anak}

a) Fasilitas Belajar Anak

Ruang belajar anak di Kota Pekanbaru masih terglong sangat sedikit, seharusnya ruang belajar anak ada di tempat fasilitas umum terutama instansi pemerintah sejalan dengan yang diucapkan oleh ibu Nel Afni L, SKM, M.K.M selaku Kepala seksi Pemenuhan Hak Anak Di Bidang Hak Sipil, Informasi dan Partisispasi, beliau mengatakan:

"Ruang belajar anak memang masih minim, sekarang ini Cuma ada satu di Kantor Camat Rumbai Sudah Ada Ruang Baca Anak, dan PR untuk kami kedepannya menambah ruang baca anak disetiap fasilitas umu terutama instansi pemerintah, tetapi di perpustakaan kota dan propinsi sudah ada ruangan baca khusus anak"

\section{b) Fasilitas Bermain Anak}

Sejauh ini sudah banyak taman bermain anak sejalan dengan peraturan daerah yang mewajibkan membuat RTH (Ruang Terbuka hijau). Hal ini disampaikan oleh ibu ibu Nel Afni L, SKM,M.K.M selaku Kepala seksi Pemenuhan Hak Anak Di Bidang Hak Sipil, Informasi dan Partisispasi, beliau mengatakan:

Fasilitas Bermain sudah banyak taman bermain anak, Taman Kota Pekanbaru, 
Ruang Terbuka Hijau Putri Kaca Mayang, Science Park Universitas Riau, Ruang Terbuka arifin Ahmad, Ruang Terbuka Hijau Tunjuk Ajar Integritas, tetapi dari tempai ini semua belum terlalu pro anak atau belum dapat sepenuhnya memenuhi hak anak. Dari segi keamanan masih ada kemungkinan anak berlari ke jalan raya karna pagar belum memenuhi syarat aman untuk anak-anak, fasilitas yang masih jauh dari kenyamanan anak, ini juga menjadi PR buat kami supaya mendapatkan penghargaan KLA"

c) Forum Anak

Forum Anak sudah ada 1 per kecamatan dan juga masing- masing kelurahan mempunya 1 forum anak, setiap tahun selalu dikukuhkan oleh DPPPA, tahun ini ada tambahan yang sebelum nya 12 sekarang menjadi 13 yang dikukuhkan pada tanggal 1 Oktober. Ibu Nel Afni L, SKM,M.K.M selaku Kepala seksi Pemenuhan Hak Anak Di Bidang Hak Sipil, Informasi dan Partisispasi, beliau mengatakan:

"Kita memiliki Fankoper (Forum Anak Kota Pekanbaru) yang menampung ornagisasi2 anak di kota pekanbaru. Dengan membawa anak- anak ikut serta dalam perumusan kebijakan bersama anggota dewan, anak-anak yang di ikut sertakan adalah anak yang sudah sekolah tingakat SLTP dan SLTA, kemudian Fankoper ini juga tempat mengadukan keluhan-keluhan anak dan juga media mediasi apabila ada anak yang bermasalh"

Tabel 2. Jumlah Forum Anak di Kota Pekanbaru

\begin{tabular}{cll}
\hline No & \multicolumn{1}{c}{ Kecamatan } & \multicolumn{1}{c}{ Nama Forum Anak } \\
\hline 1 & Bukit Raya & Forum Anak Bukit Raya (FORKITA) \\
2 & Limapuluh & Forum Anak Limapuluh (FALIMPUL) \\
3 & Marpoyan Damai & Forum Anak Marpoyan Damai (FANDA) \\
4 & Payung Sekaki & Forum Anak Payung Sekaki (FANGKI) \\
5 & Pekanbaru Kota & Forum Anak Pekanbaru Kota (FORKITA) \\
6 & Rumbai & Forum Anak Rumbai (FARUM) \\
7 & Rumbai Pesisir & Forum Anak Rumbai Pesisir (FANRUMPES) \\
8 & Sail & Forum Anak Sail (FASA) \\
9 & Senapelan & Forum Anak Senapelan (FASENAP) \\
10 & Sukajadi & Forum Anak Sukajadi (FASUKA) \\
11 & Tampan & Forum Anak Tampan \\
12 & Tenayan Raya & Forum Anak Tenayan Raya (FAKTA) \\
\hline
\end{tabular}

\section{Faktor-Faktor Penghambat dalam Pelaksanaan KLA}

Dalam pelaksanaan kebijakan pasti ditemukan hambatan-hambatandalam proses pelaksanaan tersebut baik dari pihak internal ataupun eksternal. Hasil wawancara dengan pihak DPPPA dan Disdukcapil Kota Pekanbaru terdapat beberapa kendala yaitu : Memang sudah ada RAD di dalam APBD untuk pelaksananan program KLA ini tetapi sejauh ini masih sangat kurang malah jauh dari kata cukup, ini disampaikan oleh Ibu
Nel Afni L, SKM,M.K.M selaku Kepala seksi Pemenuhan Hak Anak Di Bidang Hak Sipil, Informasi dan Partisispasi, beliau mengatakan:

\section{"dalam pelaksanaan program KLA ini kita berhadapan dengan faktor penghalang yaitu, biaya, regulasi dan SDM ini menjadi momok dalam pelaksanaan KLA"}

Selain biaya juga SDM mempengaruhi karna sering nya ada pergantian pejabat sehingga sehingga perlu di sosialisasikan 
kembali ke pejabat yg baru tentang KLA. Kemudian regulasi yang belum terlalu mengikat semua OPD untuk bersinergitas secara total dalam mewujutkan program KLA ini.

\section{PENUTUP}

\section{Implementasi Program Kota Layak} Anak Dalam Memenuhi Hak Sipil Dan Kebebasan Anak Di Kota Pekanbaru

a) Penguatan Kelembagaan

Pelaksanan Program Kota Layak Anak di Kota Pekanbaru sudah semakin bagus dari pada sebelumnya, pertama dilihat dari segi penghargaan yang diberikan pemerintahan pusat pada tahun 2019 mendapatkan 3 penghargaan, sebagai KLA kriteria Nindya, Sekolah Ramah Anak dan Puskesmas Ramah Anak. Pada tahun sebelumnya 2018 Kota Pekanbaru naik peringkat dengan meraih pratama ke Madya atau peringkat ketiga Kota Layak Anak (KLA). Terlepas dari penghargaan tersebut peneliti menemukan hasil bahwa yang menyumbang nilai tinggi itu adalah bidang pendidikan dan kesehatan.

Dalam hal penguatan kelembagaan, Pemerintah Daerah sudah mempunyai peraturan turunan tentang penyelengaraan Program Kota Layak Anak yang sekarang proses nya sedang menunggu No register di pemerintahan Propinsi. Kemudian tujuan dan sasaran dari kebijakan tersebut adalah pemenuhan hak anak, maka Pemerintah Kota Pekanbaru sudah mendengarkan aspirasi dari anak-anak yang ada di Kota Pekanbaru melalu Fankoper (Forum Anak Kota Pekanbaru) yang menampung ornagisasi2 anak di kota pekanbaru. Dengan membawa anak- anak ikut serta dalam perumusan kebijakan bersama anggota dewan, anak-anak yang di ikut sertakan adalah anak yang sudah sekolah tingakat SLTP dan SLTA.

Untuk Sumber daya manusia sudah ada Gugus Tugas (GT) sampai sekarang berfungsi, didalam GT ini sudah diatur peran dan tugas masing. Keseriusan Pemkot juga terlihat disini dengan memberikan pelatihan rurin, yang terbaru ini Dinas
Pemberdayaan Perempuan dan

Perlindungan Anak Provinsi Riau menyelengarakan pertemuan "Bimbingan Teknis Gugus Tugas Kabupaten/Kota Layak Anak (KLA) Dengan Analisis Pengarusutamaan Hak Anak (PUHA) Angkatan Kedua Tahun 2019 pada tanggal 03-04 September 2019 bertempat di Hotel Jatra. Anggota GT adalah seluruh perangkat daerah yang terkait dengan diketuai oleh SEKDA.

Kemudian sumber dana semua dari PAD belum ada kerjasama dengan pihak swasta tapi ini menjadi PR untuk kedepannya, walaupun sudah ada APSAI (Asosiasi Perusahaan Sahabat Anak Indonesia) belum aktif karna baru terbentuk.

b) Hak Sipil dan Kebebasan Anak

Indikator hak sipil dan kebebasan anak sudah beranjak bagus juga dari sebelum nya. Terlihat dari data anak yang memiliki akte kelahiran yang yang tahun 2017 sbanyak 75\% 2018 sebanyak 81,03\% pada tahun 2019 menjadi 92\%. Angka ini belum cukup untuk menambah nilai Kota Layak Anak, karna targen KLA adalah 100\%.

Untuk mempercepat peningkatan menjadi $100 \%$ disdukcapil sudah membuat inovasi jemput bola, langsung turun ke UPTD minta data, kemudian juga bekerjasama dengan pihak sekolah. Kemudian penghapusan denda bagi yang terlambat mengurus Akte kelahiran. Sementara dari hasil penelitian juga didapat bahwa yang menyumbng data kekurangan $100 \%$ ini adalah para pendatang dan masyarakat yang kurang mampu.

Kemudian dalam Hal Penerbitan KIA (Karti Identitas Anak) memang Kota Pekanbaru Terlambat dari Kota Lain, tengah tahun ini saja masih mengumpulkan data, tetapi dalam dua bulan terahir sudah dilakukan pencetakan KIA. KIA ini juga Disdukcapil memakai sistem jempu bola dengan kerjasama dengan UPTD dan Dinas pendidikan. Dan sementara ini mereka fokus untk anak SLTP ke bawah karna 
pertimbangan tingkat SLTA sebentar lagi akan dapat KTP.

Dalam hal Akte Kelahiran dan KIA ini disdukcapil juga membuat inovasi lain, selain jemput bola, Disdukcapil sudah melakukan MOU dengan Rumah sakit yang ada di Kota Pekanbaru, sejauh ini masih tingat Rumah Sakit tetapi meningkat dari 23 sekarang sudah 27 walau masih ada yang belum aktif.

Fasilitas belajar dan bermain anak, sejauh ini menjadi PR untuk menigkat kan karena fasum blum banyak yang memiliki ruang baca anak, samapai saat ini baru ada di Kantor Camat Rumbai Sudah Ada Ruang Baca Anak. Untk Fasilitas Bermain sudah banyak taman bermain anak, Taman Kota Pekanbaru, Ruang Terbuka Hijau Putri Kaca Mayang, Science Park Universitas Riau, Ruang Terbuka arifin Ahmad, Ruang Terbuka Hijau Tunjuk Ajar Integritas, tetapi dari tempai ini semua belum terlalu pro anak atau belum dapat sepenuhnya memenuhi hak anak.

Forum Anak sudah ada 1 per kecamatan dan juga masig- masing kelurahan mempunya 1 forum anak, setiap taun selalu dikukuhkan oleh DPPPA, tahun ini ada tambahan yang sebelum nya 12 sekarang menjadi 12 .

Faktor-Faktor Penghambat pelaksanan Program Kota Layak dalam Memenuhi Hak Sipil dan kebebasan Anak

Faktor prnghambat ada 3 yaitu dana, SDM dan regulasi, Memang sudah ada RAD di dalam APBD untuk pelaksananan program KLA ini tetapi sejauh ini masih sangat kurang malah jauh dari kata cukup. Selain biaya juga SDM mempengaruhi karna sering nya ada pergantian pejabat sehingga sehingga perlu di sosialisasikan kembali ke pejabat yg baru tentang KLA. Kemudian regulasi yang belum terlalu mengikat semua OPD untuk bersinergitas secara total dalam mewujutkan program KLA ini.

\section{DAFTAR KEPUSTAKAAN}

Abdul Wahab, Solichin. 2004. Analisis Kebijaksanaan dari Formulasi keImplementasi Kebijaksanaan Negara. Jakarta: Bumi Aksara.

Abidin, Said Zainal. 2008. Strategi Kebijakan dalam Pembangunan dan Ekonomi Politik. Jakarta: Suara Bebas.

Arikunto, Suharsimi. 2006. Prosedur Penelitian Suatu Pendekatan Praktik Edisi Revisi. Jakarta: Rineka Cipta.

Budi Winarno, 2002.Kebijakan Publik; Teori dan Proses.Media Presindo Yogyakarta.

Edward, George. C. 1980. Implementing Public Policy. Washington D.C: Congresional Quarterly Inc.

Moleong, Lexy J. (2007) Metodologi Penelitian Kualitatif, Penerbit PT Remaja Rosdakarya Offset, Bandung.

Panduan Kebijakan Pengembangan Kota Layak Anak, Kementerian Pemberdayaan Perempuan Republik Indonesia. Tahun 2006 Anak.

Peraturan Mentri Pemberdayaan Perempuan dan Perlindungan Anak Republik Indonsia No 11 Tahun 11 Tentang Kebijakan Pengembangan Kabupaten/Kota Layak.

Peraturan Menteri Negara Pemberdayaan Perempuan dan Perlindungan Anak No 12 Tahun 2011 tentang Indikator Kabupaten/ Kota Layak Anak.

Peraturan Menteri Negara Pemberdayaan Perempuan dan Perlindungan Anak No 13 Tahun 2011 tentang Panduan Pengembangan Kabupaten/ Kota Layak Anak.

Sugiyono. 2007. Metode Penelitian Kuantitatif Kualitatif dan $R \& D$. 
Bandung: Alfabeta.

Tangkilisan, Hessel Nogi S. 2003.Kebijakan Publik Untuk Pemimpin Berwawasan Internasional. Blairung \& Co, Yogyakarta.

UU No. 4 Tahun 1979 Tentang Kesejahteraan Anak.

UU No. 23 Tahun 2002 tentang Perlindungan Anak.

UU No 23 tahun 2002 tentang
Perlindungan Anak.

William N. Dunn, 2003. Pengantar Analisis Kebijakan Publik, Gadjah Mada University Press: Yogyakarta. Terjemahan, Tangkilisan, 2003: 1).

http://www.kpai.go.id/artikel/pemenuhanhak-anak-atas-akta-kelahiranmerupakan-bagian-dari-hak-sipilyang-harus-dilindungi-konstitusi.

https://id.wikipedia.org/wiki/Hakhak_sipil_dan_politik 